\title{
The incidence of peripheral nerve injury in trauma patients in Iran
}

\author{
İran'da travma hastalarındaki periferik sinir hasarının insidansı
}

\author{
Soheil SAADAT, Vahid ESLAMI, Vafa RAHIMI-MOVAGHAR
}

\section{BACKGROUND}

In patients aged 1-34 years, injury is the leading cause of mortality, disability and health care costs. Two to $3 \%$ of Level I trauma patients have peripheral nerve injury (PNI).

\section{METHODS}

Data were collected from the Iran National Trauma Registry database, compiled according to the International Classification of Diseases, 9th revision (ICD9) codes, from August 1999 to February 2004. The information included demography, mechanism, levels and regions of PNI, associated injuries, Abbreviated Injury Scale, duration of hospital stay, and costs.

\section{RESULTS}

Of 16,753 patients, 219 (1.3\%) had PNI; $182(83.1 \%)$ were male. The mean age of the patients with PNI was lower than of those without nerve injury $(28.6 \pm 14.45$ vs. $33 \pm 21.08$ years; $p<0.001)$. The most common cause of PNI was direct laceration from a sharp object (61\%) followed by road traffic crashes $(22 \%)$. Penetrating trauma was more common than non-penetrating injuries $(5.6 \%$ vs. $0.4 \%, \mathrm{p}<0.001)$. The most frequent PNI location was from the elbow to the hand $(10 \%)$. The ulnar nerve was the most commonly injured nerve. The most common area of ulnar nerve injury was at the forearm $(15.3 \%)$.

\section{CONCLUSION}

Sharp laceration and road traffic crash have the highest rates of PNI, which are more common in young males. Open wounds from the elbow to the hand should raise suspicion of PNI in triage. Although injuries leading to PNI are rare, their outcomes and disabilities require further research.

Key Words: Extremity trauma; incidence; peripheral nerve injury; road traffic crashes.

\begin{abstract}
$\boldsymbol{A M A C}$
Bir-34 yaşındaki hastalarda yaralanma önde gelen mortalite, sakatlık ve sağlık bakım gideri nedenidir. Birinci seviye travma hastalarının \%2'si ile \%3'ü periferik sinir hasarina (PSH) sahiptir.
\end{abstract}

\section{GEREÇ VE YÖNTEM}

Veriler Ağustos 1999'dan Şubat 2004'e kadar olan zaman aralığı içinde ICD9-kodlarına göre İran Ulusal Travma Kayit veritabanından toplandi. Bilgiler demografi, PSH'ye ilişkin mekanizma, seviyeler ve bölgeler ile eşlik eden hasarlar, Kısaltılmış Hasar Skalası, hastanede kalma süresi ve hastane giderlerini içerdi.

\section{BULGULAR}

16,753 hastanın 219'u (\%1,3) PSH'li ve 182'si $(\% 83,1)$ erkek idi. PSH'li hastaların ortalama yaşı, sinir hasar1 olmayan hastalarınkine göre daha düşük bulundu $(28.6 \pm 14.45$ ve $33 \pm 21,08$ yaş; $\mathrm{p}<0,001)$. En yaygın $\mathrm{PSH}$ nedeni, keskin cisimden kaynaklanan direkt laserasyondu (\%61) bunu karayolu trafik kazaları (\%22) izledi. Penetran travma, penetran yaralanmalara göre daha yaygınd 1 ( $\% 5,6$ ve $\% 0,4, p<0,001)$. En sik PSH, dirsek ile el bölgesinde görüldü. (\%10). Ulnar sinir, en sık olarak yaralanan sinirdi. Ulnar sinir yaralanmasına ilişkin en yaygın alan, ön kol oldu $(\% 15,3)$.

\section{SONUÇ}

Keskin laserasyon ve trafik kazası, genç yaş erkeklerde daha sık olan PSH'ye ilişkin en yüksek oranlara sahiptir. Dirsekten itibaren ele doğru olan açık yaralar, triyajda PSH'ye ilişkin kuşkuyu artırmalıdır. PSH'ye yol açan yaralanmalar nadir olmakla birlikte, bunların sonuçları ve sakatlıkları daha ileri araştırma gerektirmektedir.

Anahtar Sözcükler: Ekstremite travması; insidans; periferik sinir yaralanması; karayolu trafik kazaları. 
Trauma is the most common cause of death among people 1 to 34 years of age, a chief cause of disability and years of life lost, and a main contributor to health care costs. ${ }^{[1]}$ Trauma to the peripheral nerve results in significant disability across the world. ${ }^{[2]}$ The most causative factor for trauma entirely, ${ }^{[3]}$ and of peripheral nerve injury (PNI) specifically, is road traffic crash (RTC). Data from developed countries are useful but insufficient for strategic long-term planning in developing countries. ${ }^{[4]}$

In this study, the incidence of PNI and the related factors in trauma patients in Iran are discussed.

\section{MATERIALS AND METHODS}

Our research is a retrospective cross-sectional study. The data were collected from the Iran National Trauma Registry database from August 1999 to February 2004. The data were acquired from important hospitals in eight major cities of Iran. Each case that was admitted because of trauma and had a hospitalization period of more than 24 hours was included in the database. A PNI was defined as an injury to a nerve in the upper or lower extremities. The PNI, associated injuries and mechanism of trauma were classified based on the International Classification of Diseases, 9th revision (ICD-9) from S00 to S99 for a single region and T00 to T07 for multiple regions. Patients with exclusively nerve root, brachial or lumbar plexus were excluded. Diagnosis of a PNI was made by neurologic examination of general physicians in the emergency room and confirmed by specialists and electrodiagnostic evaluations. The information obtained from the original database included the patients' general characteristics, mechanism of trauma (such as RTC, fall, cuts from a sharp object), traumas (such as open wounds, fractures), levels and regions of PNIs, Abbreviated Injury Scale (AIS), duration of hospital stay, and final disposition/outcome.

The AIS scores were used to classify injury severity and were assigned to all traumas noted in the diagnostic record of hospitalized patients with PNI. ${ }^{[5-7]}$

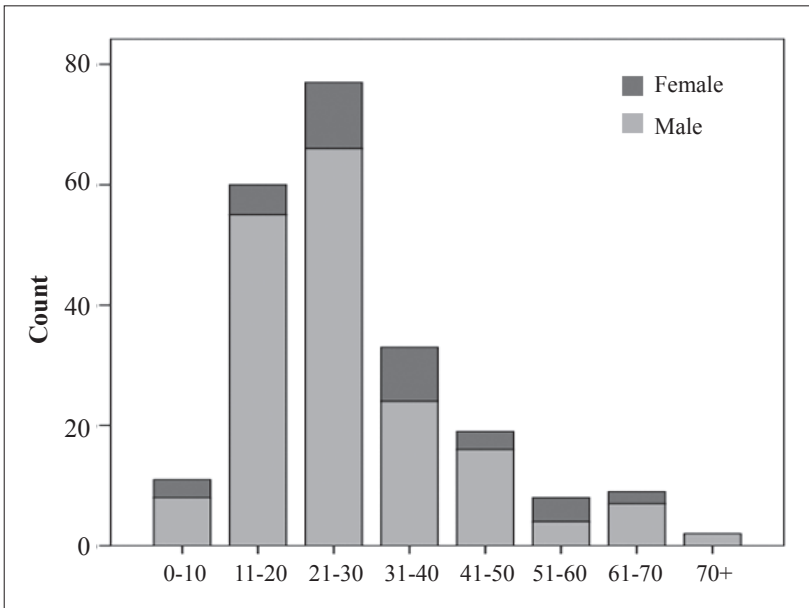

Fig. 1. Number of peripheral nerve injuries for each age-sex category.

The Injury Severity Score (ISS) was computed by the sum of squares of the highest AIS score in the three body regions with the most injury. Statistical analysis was conducted consisting of Student's t test and non-parametric tests including the Mann-Whitney $U$ test and Kruskal-Wallis test to compare means and chi-square testing, where appropriate. The significance level was set at 0.05 . Statistical analyses were conducted using the Statistical Package for the Social Sciences (SPSS) 14.0 (SPSS Inc, Illinois, USA) and STATA 10 (Statacorp, Texas, USA).

\section{RESULTS}

The study subjects consisted of 16,753 trauma patients. They presented with 23,729 traumas. Ninety percent of the patients were younger than 50 years. The two most common mechanisms of trauma were RTC $(58 \%)$ and fall (25\%). Distribution of extremity traumas in age groups are displayed in Table 1. Two hundred and nineteen patients $(1.3 \%)$ were found to have PNI. Of these, 182 (83.1\%) were male and 37 (16.9\%) female. The mean age of patients with PNI was lower than of those without nerve injury $(28.6 \pm 14.45$ vs. $33 \pm 21.08$ years, $p<0.001$ ). Distribution of PNI among age groups in both sexes is depicted in Figure 1. PNI

Table 1. Distribution of extremity traumas according to age group

\begin{tabular}{|c|c|c|c|c|c|c|c|c|}
\hline $\begin{array}{l}\text { Age } \\
\text { group }\end{array}$ & $\begin{array}{c}\text { Total, } \% \\
\mathrm{n}=16709 \\
(100 \%)\end{array}$ & $\begin{array}{c}\text { Open wound, \% } \\
\mathrm{n}=3878 \\
(23.2 \%)\end{array}$ & $\begin{array}{c}\text { Fracture, } \% \\
n=10,497 \\
(62.8 \%)\end{array}$ & $\begin{array}{c}\text { Joint/ligament, \% } \\
\mathrm{n}=878 \\
(5.3 \%)\end{array}$ & $\begin{array}{l}\text { Nerves, \% } \\
\mathrm{n}=235 \\
(1.4 \%)\end{array}$ & $\begin{array}{l}\text { Blood vessels, \% } \\
\qquad \begin{array}{c}\mathrm{n}=216 \\
(1.3 \%)\end{array}\end{array}$ & $\begin{array}{l}\text { Muscle tendons, } \% \\
\mathrm{n}=874 \\
(5.2 \%)\end{array}$ & $\begin{array}{l}\text { Crushing, \% } \\
n=131 \\
(0.8 \%)\end{array}$ \\
\hline $0-10$ & 8.6 & 6.6 & 10.2 & 4.1 & 5.5 & 6.5 & 3.4 & 8.4 \\
\hline $11-20$ & 24.1 & 26.5 & 22.6 & 21.4 & 26.0 & 31.0 & 31.0 & 29.0 \\
\hline $21-30$ & 25.4 & 33.5 & 20.6 & 29.0 & 33.6 & 35.6 & 39.0 & 25.2 \\
\hline $31-40$ & 13.6 & 15.1 & 12.6 & 15.9 & 17.0 & 17.1 & 14.6 & 21.4 \\
\hline $41-50$ & 8.7 & 8.0 & 9.3 & 9.9 & 8.5 & 2.8 & 5.7 & 5.3 \\
\hline $51-60$ & 6.6 & 4.6 & 7.5 & 8.7 & 4.3 & 2.8 & 3.0 & 6.1 \\
\hline $61-70$ & 7.1 & 4.1 & 8.8 & 7.1 & 3.8 & 2.8 & 2.1 & 2.3 \\
\hline $71+$ & 6.0 & 1.8 & 8.4 & 3.9 & 1.3 & 1.4 & 1.1 & 2.3 \\
\hline
\end{tabular}




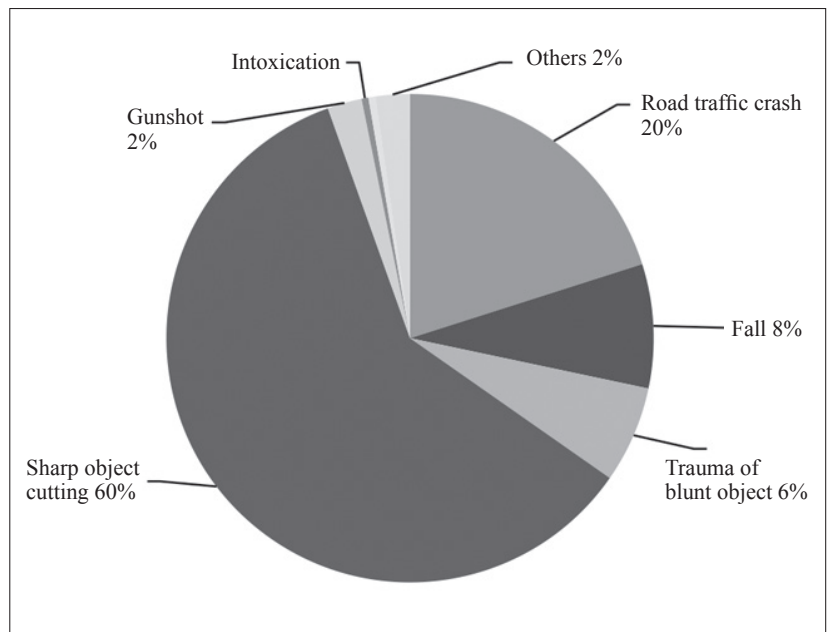

Fig. 2. Mechanism of trauma in peripheral nerve-injured patients.

was most common in the 21-30 years of age group $(34 \%)$.

\section{Mechanism of Trauma}

The most common mechanism of trauma in patients who experienced PNI was sharp object laceration (61\%) followed by RTC (22\%) (Fig. 2). Considering all RTC patients $(9,717)$, the most common victims were pedestrians (41\%). However, PNI-related RTCs were most common in car occupants $(\mathrm{N}=78 ; 0.8 \%)$. Among car occupants, PNI was more common in front seat passengers.

\section{Trauma}

Eleven percent of all traumas were penetrating $(2,642$ out of 23,720$)$. However, in PNI patients, the frequency of penetrating trauma was more than of nonpenetrating injuries $(5.6 \%$ vs. $0.4 \% ; \mathrm{p}<0.001)$. PNI was associated with $4.9 \%$ of open wounds and $0.4 \%$ of fractures (Table 3 ). Figure 3 shows the distribution of these lesions in the extremities of PNI patients. The most common open wounds associated with PNI were wounds from the elbow to the hand region (Fig. 3).

\section{Specific Anatomical Nerves}

Nerves: The ulnar nerve was the most commonly injured nerve (Fig. 4). In the upper extremity, the order of the most frequently injured nerves was ulnar, digital, median, and radial. In the lower limbs, the most commonly injured nerves were the common peroneal nerve followed by tibial nerve. Distribution of PNIs and associations with fractures and open wounds are shown in Figure 4.

\section{Regions}

Peripheral nerve injury (PNI) was more common in the upper extremities $(83.9 \%)$ than lower extremities. The ulnar nerve was most commonly injured at the forearm level. The ulnar nerve injury at the forearm

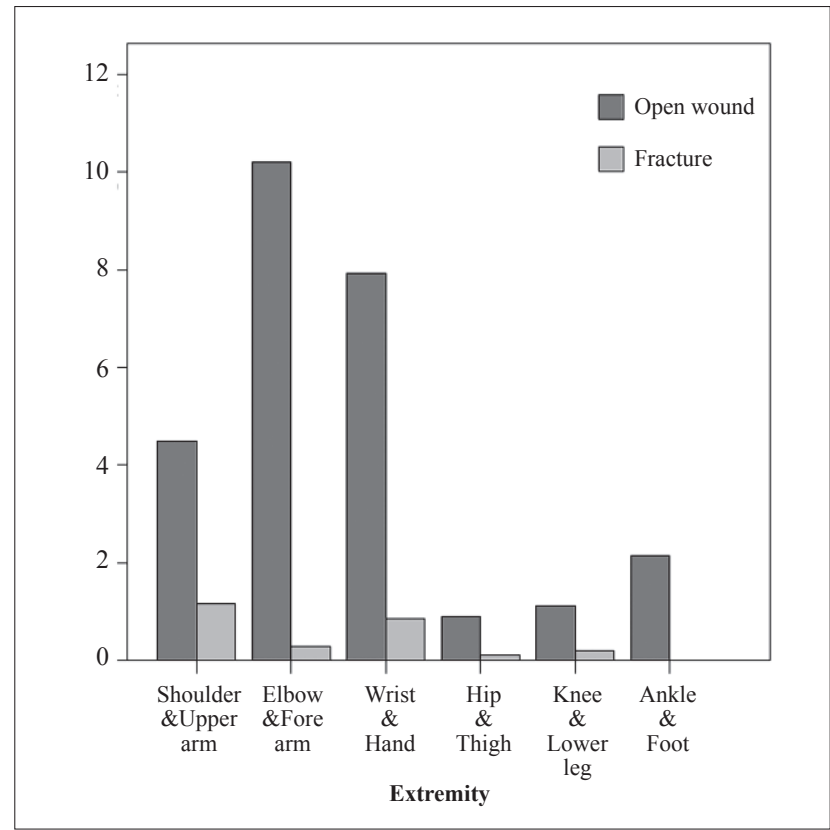

Fig. 3. Distribution of peripheral nerve injuries in different extremity regions and the association with fractures and open wounds.

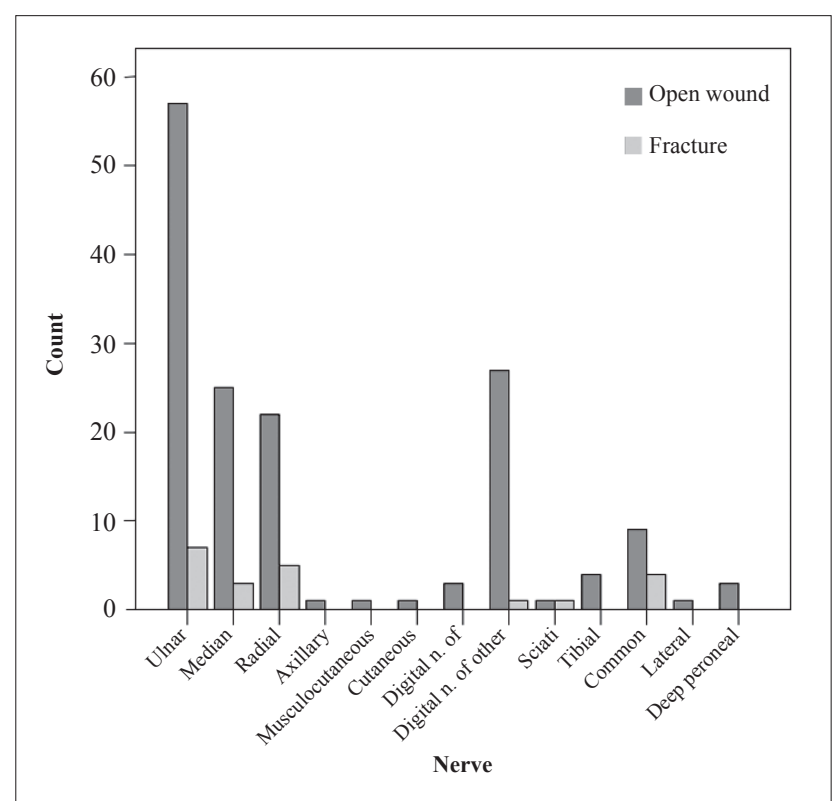

Fig. 4. Distribution of peripheral nerve injuries and the association with fractures and open wounds.

level (S 54.0) alone constituted $15.3 \%$ of all PNIs.

\section{Injury Severity Score (ISS)}

The PNI patients presented with lower ISS than other trauma patients $(5.5 \pm 5.8$ vs. $7.1 \pm 7.5)$, and the difference was statistically significant $(p<0.001)$. In PNI patients, the highest ISS was associated with the tibial nerve (Table 2).

\section{Length of hospital stay and expenses}

The average length of hospital stay for all trauma 
Table 2. ISS in different nerve injures

\begin{tabular}{|c|c|c|c|}
\hline \multicolumn{2}{|l|}{ Upper extremity } & \multicolumn{2}{|c|}{ Lower extremity } \\
\hline Nerve & ISS & Nerve & ISS \\
\hline Ulnar & $5.09 \pm 2.30$ & Sciatic & $6.29 \pm 3.86$ \\
\hline Median & $6.73 \pm 13.10$ & Tibial & $8.25 \pm 2.22$ \\
\hline Radial & $5.64 \pm 2.55$ & Peroneal & $7.40 \pm 2.38$ \\
\hline Axillary & $4.50 \pm 0.71$ & Deep peroneal & $5.67 \pm 2.89$ \\
\hline Digital, thumb & $2.00 \pm 1.73$ & & \\
\hline Digital, others & $2.87 \pm 1.93$ & & \\
\hline
\end{tabular}

patients was $5.92 \pm 6.19$ days and the mean hospital expenses were 1,656,428 $\pm 3,287,094$ Rials. The mean hospital stay in PNI patients was less than in other trauma patients $(6.0 \pm 6.02$ vs. $6.8 \pm 7.9$ days; $\mathrm{p}<0.05)$. Hospital duration and expenses with different nerve injuries are summarized in Table 4.

\section{DISCUSSION}

This study showed that the incidence of PNI is $1.3 \%$ in trauma patients in trauma hospitals in Iran. The PNI incidence rate has been determined as 13.9 per 100,000 person years. ${ }^{[8]}$ In other studies, $2-3 \%$ of Level I trauma patients have PNI, ${ }^{[9-11]}$ and the incidence of PNIs following limb trauma was $1.64 \% .{ }^{[10]}$

Fractures of adjacent bones are generally associated with PNI. ${ }^{[2,12]}$ Most of the PNIs are single rather than multiple nerve injuries. ${ }^{[13]}$

The high incidence of PNI in male patients is reflected in other sources in the literature. ${ }^{[9,10,13-16]}$ The exception for this rule can be seen in the study of Taylor et al., ${ }^{[6]}$ which reported almost equal PNI in males and females. Additionally, Ahrari et al. ${ }^{[9]}$ reported $52 \%$ of male injury in the Bam earthquake, which may be due to almost similar involvement of both sexes in disasters .

The higher incidence of PNI in males could be related to high-risk occupations and cultural issues. In addition, women are not accustomed to riding motorcycle in Iran. ${ }^{[4]}$
Our study showed that $90 \%$ of the trauma patients were under 50 years old, and the peak frequency of PNI was identified in the 21-30-year-old age group, which shows the higher vulnerability of the youth. $[9,10,13,17]$

Lower ISS and hospital stay were both suggestive of less severity of trauma in PNI patients versus those without nerve injury. This indicates that PNI is not restricted to severe injuries and its probability should not be ignored in non-severe trauma patients. ${ }^{[9]}$

In our study, laceration by a sharp object was the most common mechanism of trauma in PNI patients. The same finding can be seen in the literature, in which penetrating trauma involved PNI more than non-penetrating injury. ${ }^{[18]}$ Meanwhile, the outcome of extremity function is better in penetrating injuries. ${ }^{[19]} \mathrm{PNI}$ in association with vascular trauma is very critical. The combination of vascular injury and non-penetratingrelated PNI may result in permanent limb dysfunction. $[19,20]$

In our study, the upper extremity was involved more than the lower extremity in PNI. This finding was similar to many other studies..$^{[8,9,16,21]}$ However, in our study, the ratio of upper to lower extremity PNI was higher than that reported in previous studies.

In other situations such as sports, PNI is also more common in the upper than the lower extremities. ${ }^{[22,23]}$

Table 3. Peripheral nerve injury (PNI) prevalence according to the fractured bone

\begin{tabular}{|c|c|c|c|c|c|c|c|}
\hline \multicolumn{2}{|c|}{ Leg and Lower Limb } & \multicolumn{2}{|c|}{ Shoulder and Upper Limb } & \multicolumn{2}{|l|}{ Hand } & \multicolumn{2}{|l|}{ Foot } \\
\hline Bone name & $\begin{array}{c}\text { PNI Rate } \\
(\%)\end{array}$ & Bone name & $\begin{array}{c}\text { PNI Rate } \\
(\%)\end{array}$ & Bone name & $\begin{array}{l}\text { PNI Rate } \\
(\%)\end{array}$ & Bone name & $\begin{array}{c}\text { PNI Rate } \\
(\%)\end{array}$ \\
\hline Femur & 0.1 & Clavicle & 0.9 & Scaphoid & 0.0 & Calcaneus & 0.0 \\
\hline Tibia & 0.5 & Scapula & 1.4 & Other carpals & 5.3 & Talus & 0.0 \\
\hline Fibula & 0.4 & Humerus & 2.0 & Metacarpal, 1 & 0.0 & Tarsal, others & 0.0 \\
\hline \multirow[t]{5}{*}{$\begin{array}{l}\text { Multiple } \\
\text { (tibia \& fibula) }\end{array}$} & 0.0 & $\begin{array}{l}\text { Multiple (Clavicle, } \\
\text { Scapula, Humerus) }\end{array}$ & 50.0 & Metacarpal, Others & 2.5 & Metatarsal & 1.9 \\
\hline & & Ulna & 1.7 & Metacarpal, Multiple & 0.0 & Toe, great & 0.0 \\
\hline & & Radius & 1.4 & Thumb & 6.1 & Toe, others & 0.0 \\
\hline & & Multiple & 1.0 & Fingers, Other & 2.4 & Foot, multiple & 4.3 \\
\hline & & (radius \& ulna) & & Fingers, multiple & 7.5 & & \\
\hline
\end{tabular}


Table 4. Hospital duration and expenses and the mean patients age in different nerve injuries

\begin{tabular}{llll}
\hline Nerve name & Age (years) \pm SD & Hospitalization duration (days) \pm SD & Medical expenses (Rials) \pm SD \\
\hline Ulnar & $30 \pm 14$ & $5.54 \pm 5.53$ & $2.068 .551 \pm 5.503 .734$ \\
Median & $22 \pm 9$ & $5.15 \pm 5.57$ & $1.291 .550 \pm 1.313 .244$ \\
Radial & $30 \pm 16$ & $6.25 \pm 7.94$ & $1.205 .524 \pm 1.706 .899$ \\
Axillary & $30 \pm 22$ & $1.50 \pm 0.71$ & $516.092 \pm 517.732$ \\
Musculocutaneous & 27 & 1.00 & $1.367 .740 \pm 914.933$ \\
Digital, thumb & $26 \pm 14$ & $4.00 \pm 4.36$ & $495.731 \pm 731.094$ \\
Digital, others & $27 \pm 12$ & $4.01 \pm 3.96$ & $1.086 .928 \pm 1.044 .594$ \\
Sciatic & $43 \pm 17$ & $11.86 \pm 8.57$ & $2.375 .426 \pm 1.375 .710$ \\
Tibia & $37 \pm 30$ & $8.00 \pm 6.38$ & $2.834 .179 \pm 253.8915$ \\
Common peroneal & $31 \pm 17$ & $8.06 \pm 6.68$ & $1.964 .645 \pm 1.213 .409$ \\
Lateral plantar & 56 & 30.00 & 3.900 .512 \\
Deep peroneal & $29 \pm 8$ & $5.43 \pm 4.56$ & $1.691 .296 \pm 1.646 .828$ \\
\hline
\end{tabular}

According to the Central Bank of Iran, the mean exchange of \$USD was 4891 Rials during the study period:

http://www.cbi.ir/exratesadv/exratesadv_en.aspx accessed on April 6, 2010.

In some other studies, lower extremity injury was more common than the upper extremity injury. ${ }^{[10,17]}$ A higher incidence of lower extremity injury was reported in the recent earthquake victims, which could be attributed to the position of the wounded when the earthquake occurred or to incorrect evacuation and transportation of the victims. ${ }^{[17]}$

In two studies, the most frequently injured nerve in the upper extremity was the radial nerve..$^{[9,17]}$ However, our study demonstrated that the ulnar, median and radial nerves were the most frequently injured major nerves. This sequence was also identified in other studies. ${ }^{[13,16]}$

Asplund et al. ${ }^{[4]}$ showed that the majority of PNIs occurred in the wrist and hand region. However, in our study, the forearm was the most frequently involved area, followed by the wrist and hand.

This higher involvement of nerves in the forearm, wrist and hand is due to their superficial location and the exposure of these regions in daily work with sharp cutting objects. ${ }^{[13]}$

In the lower extremity, our findings concur with those of Kouyoumdjian's study ${ }^{[1]}$ in which the peroneal nerve was the most commonly injured nerve. However, in two studies, the sciatic nerve was the most frequently injured nerve, ${ }^{[16,17]}$ followed by the peroneal nerve. ${ }^{[16]}$

In conclusion, laceration by a sharp object and RTC contribute to the highest rates of PNI, which are more common in young males. Open wounds from the elbow to the hand should raise suspicion of PNI in the triage. Although injuries leading to PNI are rare, their outcomes, physical and social disabilities and impact on health system management are areas requiring further research.

\section{REFERENCES}

1. Rivara FP, Grossman DC, Cummings P. Injury prevention. First of two parts. N Engl J Med 1997;337:543-8.

2. Robinson LR. Traumatic injury to peripheral nerves. Muscle Nerve 2000;23:863-73.

3. Beyer FR, Ker K. Street lighting for preventing road traffic injuries. Cochrane Database Syst Rev 2009:CD004728.

4. Asplund M, Nilsson M, Jacobsson A, von Holst H. Incidence of traumatic peripheral nerve injuries and amputations in Sweden between 1998 and 2006. Neuroepidemiology 2009;32:217-28.

5. Noble J, Munro CA, Prasad VS, Midha R. Analysis of upper and lower extremity peripheral nerve injuries in a population of patients with multiple injuries. J Trauma 1998;45:116-22.

6. Taylor CA, Braza D, Rice JB, Dillingham T. The incidence of peripheral nerve injury in extremity trauma. Am J Phys Med Rehabil 2008;87:381-5.

7. Selecki BR, Ring IT, Simpson DA, Vanderfield GK, Sewell MF. Trauma to the central and peripheral nervous systems. Part II: A statistical profile of surgical treatment New South Wales 1977. Aust N Z J Surg 1982;52:111-6.

8. Eser F, Aktekin LA, Bodur H, Atan C. Etiological factors of traumatic peripheral nerve injuries. Neurol India 2009;57:434-7.

9. Ahrari MN, Zangiabadi N, Asadi A, Sarafi Nejad A. Prevalence and distribution of peripheral nerve injuries in victims of Bam earthquake. Electromyogr Clin Neurophysiol 2006;46:59-62.

10. Kushwaha VP, Garland DG. Extremity fractures in the patient with a traumatic brain injury. J Am Acad Orthop Surg 1998;6:298-307.

11. Kouyoumdjian JA. Peripheral nerve injuries: a retrospective survey of 456 cases. Muscle Nerve 2006;34:785-8.

12. Heidari P, Zarei MR, Rasouli MR, Vaccaro AR, RahimiMovaghar V. Spinal fractures resulting from traumatic injuries. Chin J Traumatol 2010;13:3-9.

13. Civil ID, Schwab CW. The Abbreviated Injury Scale, 1985 revision: a condensed chart for clinical use. J Trauma 1988;28:87-90.

14. MacKenzie EJ, Steinwachs DM, Shankar B. Classifying trauma severity based on hospital discharge diagnoses. Validation of an ICD-9CM to AIS-85 conversion table. Med Care 1989;27:412-22. 
15. MacKenzie EJ, Siegel JH, Shapiro S, Moody M, Smith RT. Functional recovery and medical costs of trauma: an analysis by type and severity of injury. J Trauma 1988;28:281-97.

16. Stone L, Keenan MA. Peripheral nerve injuries in the adult with traumatic brain injury. Clin Orthop Relat Res 1988:136-44.

17. Heidari P, Zarei MR, Rasouli MR, Vaccaro AR, RahimiMovaghar V. Spinal fractures resulting from traumatic injuries. Chin J Traumatol 2010;13:3-9.

18. Babar SM. Peripheral nerve injuries in a Third World country. Cent Afr J Med 1993;39:120-5.

19. Creagh TA, Broe PJ, Grace PA, Bouchier-Hayes DJ. Blunt trauma-induced upper extremity vascular injuries. J R Coll Surg Edinb 1991;36:158-60.

20. Nichols JS, Lillehei KO. Nerve injury associated with acute vascular trauma. Surg Clin North Am 1988;68:837-52.

21. Visser PA, Hermreck AS, Pierce GE, Thomas JH, Hardin CA. Prognosis of nerve injuries incurred during acute trauma to peripheral arteries. Am J Surg 1980;140:596-9.

22. Feinberg JH, Nadler SF, Krivickas LS. Peripheral nerve injuries in the athlete. Sports Med 1997;24:385-408.

23. Frey U. The relationship between anatomical site of injury and particular sports. Proc R Soc Med 1969;62:917-9. 